\title{
Use of Molecular Markers to Assist the Development of Inbred Lines under Open Field Conditions: the Case of Criollo Peppers (Capsicum annuum L.) from Mexico
}

\author{
Leandro PEREIRA-DIAS ${ }^{1}$, Gustavo CHÁVEZ-GONZÁLEZ ${ }^{2}$, \\ Miguel BRACHO-GIL ${ }^{1}$, Ana M. FITA ${ }^{1}$, Santiago VILANOVA ${ }^{1}$, \\ José J. LUNA-RUIZ ${ }^{2}$, Laura Eugenia PÉREZ-CABRERA², \\ José Luis ARREDONDO-FIGUEROA², \\ Adrián RODRÍGUEZ-BURRUEZO ${ }^{1 *}$
}

\author{
${ }^{1}$ Universitat Politècnica de València (UPV), Institute for Conservation and Breeding of Agrodiversity (COMAV), Camino de Vera 14, 46022, \\ Valencia,Spain; leapedia@etsiam.upv.es;mibragi@etsiamn.upv.es; anfifer@btc.upv.es; sanvina@upvnet.upv.es; \\ adrodbur@doctor.upv.es(*corresponding author) \\ ${ }^{2}$ Universidad Autónoma de Aguascalientes (UAA), Centro de Ciencias Agropecuarias, Avenida Universidad 940, Aguascalientes, Aguascalientes \\ 20131,México;gus_0430@hotmail.com;joselunaruiz11@yahoo.com.mx; leperez@correo.uaa.mx; arredondo60@hotmail.com
}

\begin{abstract}
Chile peppers are one of the most important crops in Mexico and a plethora of ecotypes can be found there. Most of them are ancient open-pollinated (OP) landraces selected by farmers for uniform phenotype but with an inherent level of genetic diversity, called criollos. In this work 15 pepper accessions, encompassing 2 criollo lines, their open-pollinated progenies, and 5 controls, were characterized with a set of 36 IPGRI descriptors and 23 SSR markers to assess the effect of open pollination in the inbreeding process. Heterozygosity levels were comprised between 12 and $47 \%$ in the progenies, which were similar or lower than those values from parent plants and similar or higher than control cultivars. Also, both progenies and parents showed similar levels of agronomic and morphological uniformity. Our results suggest that this OP program is efficient in terms of reaching enough agronomic uniformity in criollo Ancho peppers while preserving certain genetic diversity to confer adaptation to climate change.
\end{abstract}

Keywords: Chile pepper heirlooms, climate change, genetic diversity, morphological characterization, participatory breeding, simple sequence repeat (SSR)

\section{Introduction}

Peppers (Capsicum spp.) are one of the most important vegetables in the world, encompassing a worldwide production of thirty-six million $\mathrm{t}$ (FAOSTAT, 2014). Capsicum annuum is the most diverse and commonly cultivated. Since Mexico is the primary diversity centre of this species, an extraordinary range of varietal types and cultivars can be found there (DeWitt and Bosland, 1996; Kraft, 2009).

Some of the breeding efforts directed to this species in this country have been towards the improvement of valuable landraces and heirlooms (Kraft, 2009). Mexican institutions labour has been improving the criollo peppers like the Ancho type, an ancient open-pollinated (OP) landrace that may be a strong candidate as pre-breeding material or as diverse population with higher adaptation/resilience to climate change (Votava et al., 2005; Aguilar-Meléndez et al., 2009; Madosa et al., 2010). The governmental initiative consists in participatory breeding programs geared towards getting farmers involved for identification of the best individuals from their fields. Then open pollination seeds from these individuals are harvested for the next generation. This approach should provide a 
366

reasonable balance between both inbreeding and preserving the essential level of diversity for the landrace identity itself (Kraft, 2009).

The goal of this experiment was to assess phenotypic and genotypic diversity within criollo peppers as well as allele fixation levels as a result of this traditional plant breeding method.

\section{Materials and Methods}

\section{Plantmaterial}

Two accessions of OP chile Ancho type (A and B), their respective progenies (a1, a2, a3, a4 and b1, b2, b3, b4), and a set of five control varieties - three OP landraces $(\mathrm{C} 1$ : 'Serrano', C2: 'Puya', C3: 'Pasilla') and two relatively modern cultivars (M1: 'Numex Garnet' and M2: 'Modern Pasilla') were included in this experiment. Plant materials were provided by scientists of the Chile breeding program of Universidad Autónoma de Aguascalientes (UAA, Mexico) (Fig. 1).

\section{Experimental procedures}

Eight plants per accession were characterized according to thirty-six IPGRI (1995) plant, inflorescence, fruit, and seed descriptors. ANOVA and Principal Components Analysis (PCA) were calculated to assess the differences among individuals using Statgraphics Centurion XVI (StatPoint Technologies, Inc.).

Subsequently, DNA was extracted using modified CTAB method (Doyle and Doyle, 1990) from a pool of the eight plants of each accession. A 23 Single Sequence Repeat (SSR) marker collection (Minamiyama et al., 2006; Portis et al., 2006; Nagy et al., 2007; Yi et al., 2006), enriched with M13 tail and a fluorescent dye (Schuelke, 2000), was used to genotype the collection throughout capillary electrophoresis and ABI PRISM ${ }^{\circ} 3100$-Avant (Applied Biosystems, USA). Genetic parameters, such as Heterozygosity (H), Polymorphic Information Content (PIC), Principal Coordinates Analysis (PCoA), and distance matrix were calculated using GenAlex 6.5 (Peakall and Smouse, 2006) and PowerMarker 3.25 (Liu and Muse, 2005).

\section{Results and Discussion}

\section{Phenotypic characterization}

From the 36 descriptors, only 15 showed significant variation among our collection, which were used to calculate the first two principal components (PC). PC1 and PC2 explained 39.8 and $19.0 \%$ of the collection total variability, respectively. For PC1 traits like stem length, seed weight, fruit weight and shape, fruit cross-sectional corrugation (positive values) and anther colour (negative) were the most discriminant ones (Fig. 2a). PC2 showed a similar behaviour where plant and fruit traits accounted for higher discriminant values (fruit surface, nodal anthocyanin (positive values), fruit shape at blossom end, and chroma at red stage (negative value)) (Fig. 2a), as reported by PereiraDias et al. (2015) in a collection of Spanish peppers. Based on that, both OP lines and their progenies were clustered together on the right side of the graph (triangular, larger fruits), as it was expected, even though there is no clear separation of the two families, indicating that standard phenotype is maintained despite the lack of controlled pollination. In the middle, the elongated, medium size fruits with a wrinkled surface, and to the left the smaller fruits with cayenne forms, clearly separated from each other and the rest of clusters (Fig. 2b).

\section{Molecular analysis}

Six SSR markers were not reliably distinguishable and therefore excluded from the analysis. The remaining 17 SSR allowed the identification of 43 different alleles, with an average of 2.5 alleles per SSR marker, ranging between 2 and 5. PIC mean value was 0.30 (ranging from 0.19 to 0.41 ). Our results are in agreement with those from Lee $e t$ al. (2003), Portis et al. (2006) and Nagy et al. (2007), although PIC mean value was slightly lower, perhaps due to individual's relatedness.

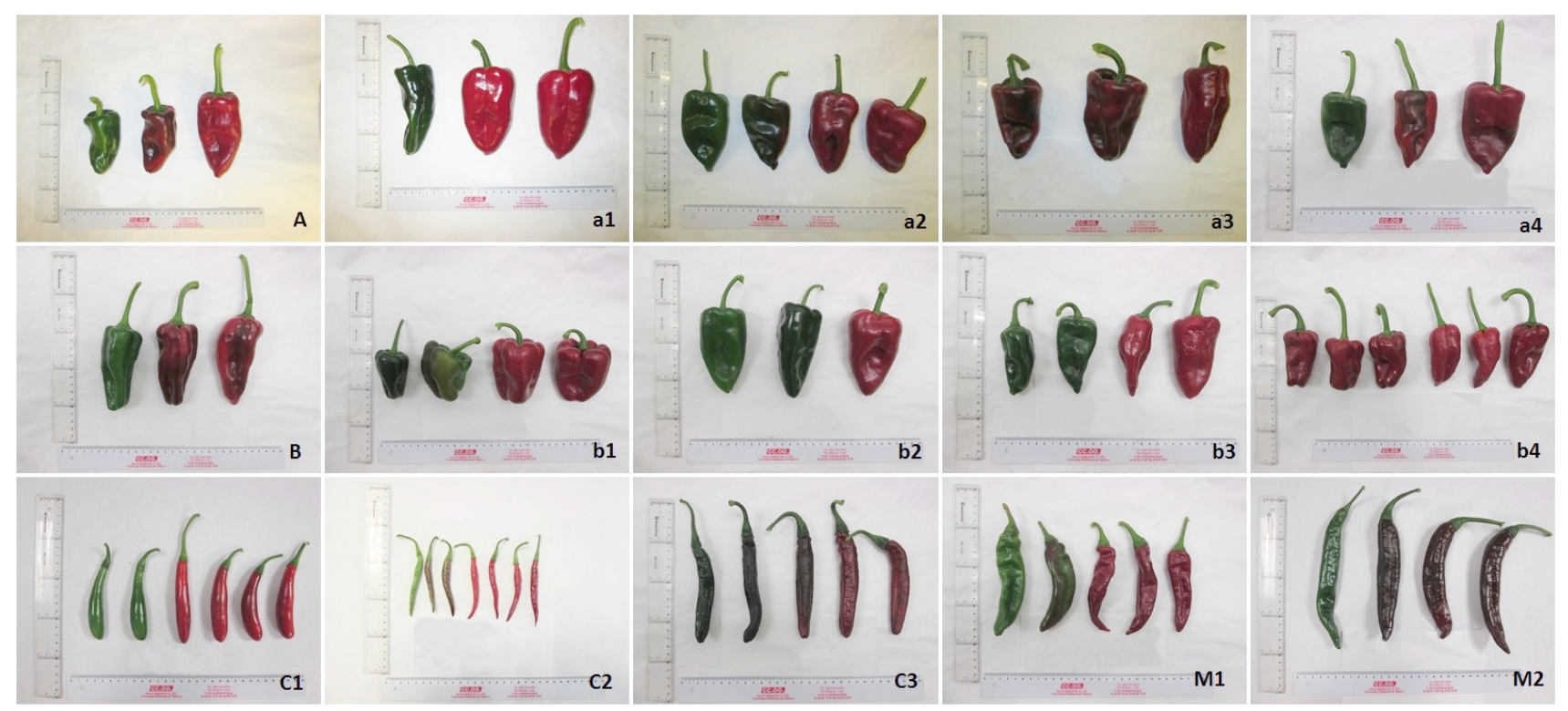

Fig. 1. Illustration of the average fruit type for each parental line, progeny, and controls. From top to bottom, left to right: parent A and progenies a1-4 (upper row); intermediate row parent B and progenies b1-4 (middle row); controls C1-3 and M1-2 (lower row) 


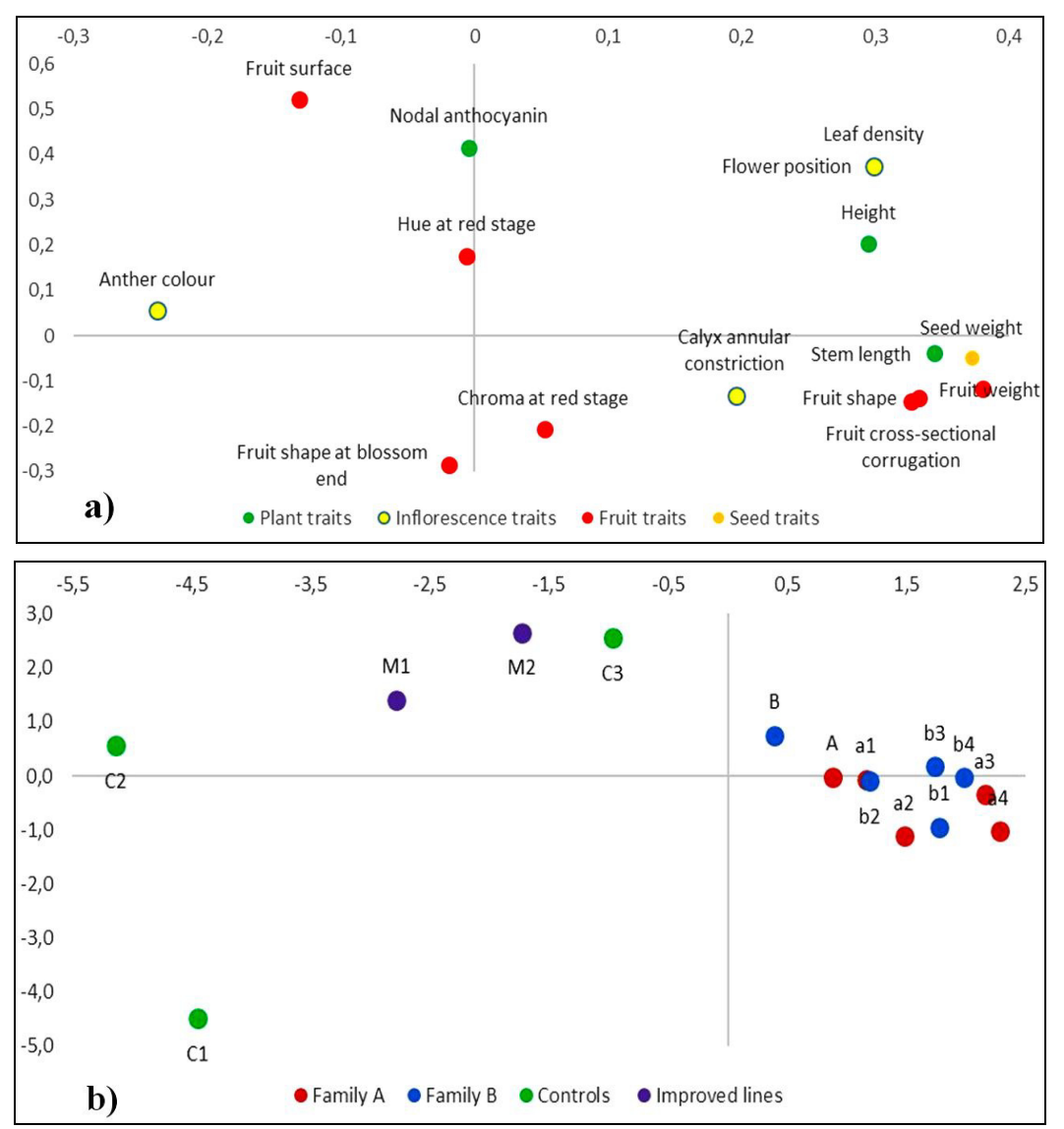

Fig. 2. PC analysis for the first two components corresponding to: i) the distribution of evaluated IPGRI descriptors (upper, Fig. 2a) for plant (green), inflorescence (yellow), fruit (red), and seed (orange) and ii) the distribution of plant accessions based on IPGRI descriptors (lower, Fig. 2b) A, B: parental lines; a1-4, b1-4: progenies; C1-3: OP landraces controls; M1-2: modern cultivars controls

Table 1. Heterozygosity values per accession and mean values for progenies

\begin{tabular}{|c|c|c|c|c|c|}
\hline Family A & Ho & Family B & Ho & Controls & Ho \\
\hline A & 0.29 & B & 0.41 & $\mathrm{C} 1$ & 0.47 \\
\hline al & 0.29 & bl & 0.29 & $\mathrm{C} 2$ & 0.12 \\
\hline a2 & 0.29 & b2 & 0.47 & C3 & 0.12 \\
\hline a3 & 0.18 & b3 & 0.12 & M1 & 0.41 \\
\hline $\mathrm{a} 4$ & 0.29 & b4 & 0.35 & M2 & 0.12 \\
\hline$\mu$ progenies & 0.26 & & 0.31 & & - \\
\hline
\end{tabular}

A, B: parent lines; al-4, bl-4: progenies; C1-3: OP landrace control; M1-2: modern cultivar.

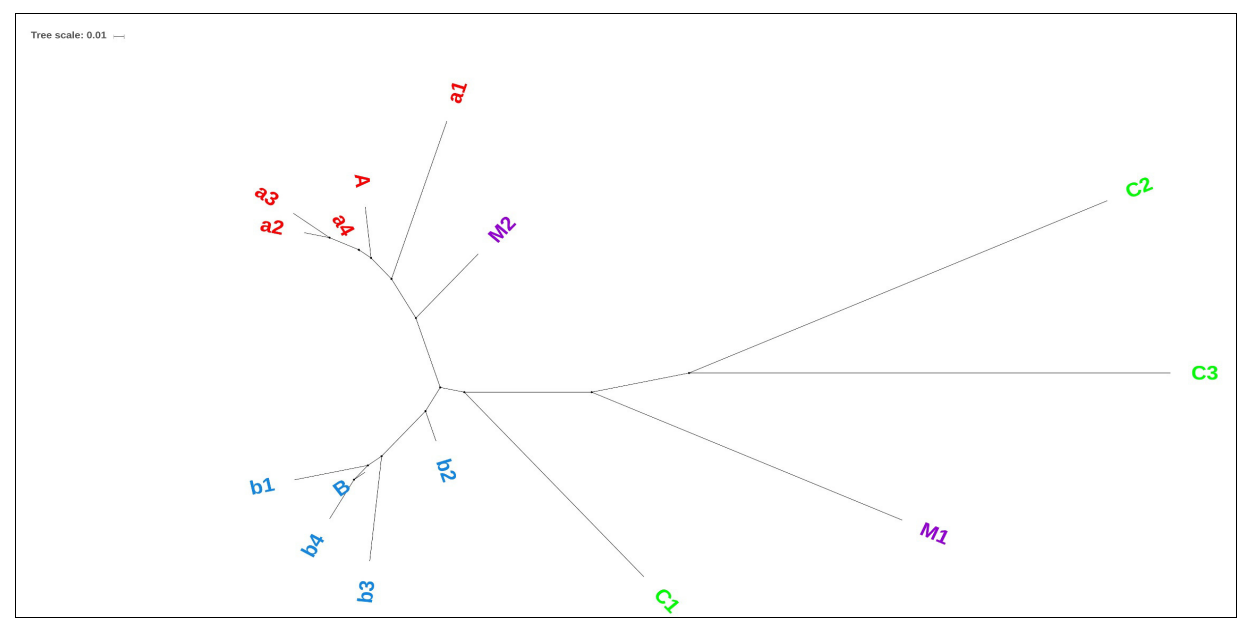

Fig. 3. iTOL's dendrogram (Letunic and Bork, 2016) based on Nei’s genetic distances (Nei et al., 1983). A, B: parental lines; a1-4, b1-4: progenies; C1-3: OP landraces controls; M1-2: modern cultivars controls 
Observed mean heterozygosity (Ho) was 30\% while mean expected heterozygosity $(\mathrm{He})$ was $37 \%$. Ho is higher than expected for an autogamous species. This result might be explained by two factors: i) DNA of eight plants per variety was pooled and ii) open-pollination conditions favoured cross-pollinations. Also, He value may be so high because of the great number of alleles present. Then as a whole, progenies A and B averaged similar or higher homozygosity than their corresponding parental lines (Table 1).

\section{Phylogenetic relationships}

Based on the genetic distance matrix a dendrogram was constructed (Fig. 3). Clearly, there are two main groups, one corresponding to family A (red) and the other one to family $\mathrm{B}$ (blue). Our results suggest that both families show enough genetic differences to be separated despite being closely related phenotypically. Even within families, different levels of genetic fixation are found among progenies and thus, some of them appear closer to the parental line than others.

\section{Conclusions}

For chile Ancho breeding a combination between individual selection with open-pollination conditions proved to be a low-cost method that allows: i) the improvement of lines as well as retaining ii) the expected morphotype inherent to the variety and iii) a certain degree of genetic diversity. The fact that progeny plants had a relatively high level of heterozygosity while being agronomically and morphologically uniform, may provide these materials resilience and adaptation to environmental stress factors and climate change.

\section{Acknowledgements}

This work was partly financed by projects INIA RTA2013-00022-C02-02 and RTA2014-00041-C02-02, funded by Instituto Nacional Investigaciones Agrarias (Spain), FEDER funds. Also, Mexican authors thank CONACYT for financing the stay of Gustavo ChávezGonzález in Spain, as well as the Programa Integral de Fortalecimiento Institucional (PIFI) de la UA de Aguascalientes (SEP-Mexico).

\section{References}

Aguilar-Meléndez A, Morrell PL, Roose ML, Kim SC (2009). Genetic diversity and structure in semiwild and domesticated Chiles (Capsicum annuum; Solanaceae) from Mexico. American Journal of Botany 96:1190-1202.

DeWitt D, Bosland PW (1996). Peppers of the world: An identification guide. Ten Speed Press, Berkeley.

Doyle JJ, Doyle JL (1990). Isolation of plant DNA from fresh tissue. Focus 12:13-15.

FAOSTAT (2014). FAOSTAT Agriculture Data. FAO, Rome. Retrieved 2017June 10 from http://fao.org/faostat.
IPGRI (1995). Descriptors for Capsicum (Capsicum spp.). International Plant Genetic Resources Institute, Rome.

Kraft KH (2009). The domestication of the chile pepper, Capsicum annuum: genetic, ecological, and anthropogenic patterns of genetic diversity. $\mathrm{PhD}$ Thesis, UCDavis, Davis.

Lee JM, Nahm SH, Kim YM, Kim BD (2003). Characterization and molecular genetic mapping of microsatellite loci in pepper. Theoretical and Applied Genetics 108:619-627.

Letunic I, Bork P (2016). Interactive tree of life (iTOL) v3: an online tool for the display and annotation of phylogenetic and other trees. Nucleic Acids Research 44:242-245.

Liu K, Muse SV (2005). PowerMarker: an integrated analysis environment for genetic marker analysis. Bioinformatics 21:2128-2129.

Madosa E, Sasu L, Ciulca S, Velicevici G, Ciulca EA, Avadanei C (2010). Possibility of use of Romanian bell pepper (Capsicum annuum L. var. grossum) local landraces in breeding process. Notulae Botanicae Horti AgrobotaniciCluj-Napoca 38(2):56-60.

Minamiyama Y, Tsuro M, Hirai M (2006). An SSR-based linkage map of Capsicum annuum. Molecular Breeding 18:157-169.

Nagy I, Stágel A, Sasvári Z, Röder M, Ganal M (2007). Development, characterization, and transferability to other Solanaceae of microsatellite markers in pepper (Capsicum annuum L.). Genome 50:668-688.

NeiM, TajimaF, Tateno Y (1983). Accuracy of estimated phylogenetic trees from molecular data. II. Gene frequency data. Journal of Molecular Evolution 19:153-170.

Peakall R, Smouse PE (2006) GENALEX 6: genetic analysis in Excel. Population genetic software for teaching and research. Molecular 6:288295.

Pereira-Dias L, Sosa JC, Rosa E, Fita A, Vilanova S, Rodríguez-Burruezo A (2015). Caracterización morfoagronómica de variedades tradicionales de pimiento (Capsicum annuum L.) mediante descriptores Capsicum y tratamiento de imagen [Morphoagronomic characterization of tradicional cultivars of paprika (Capsicum annuum L.) by means of Capsicum descriptors and image treatment software]. XIV Congreso Nacional de Ciencias Hortícolas 2015 (Orihuela, Spain, 3-5 June 2015). Actas de Horticultura 71:549-552.

Portis E, Nagy I, SasváriZ, Stágel A, Barchi L, Lanteri S (2006). The design of Capsicum spp. SSR assays via analysis of in silico DNA sequence, and their potential utility for genetic mapping. PlantScience 172:640-648.

Schuelke M (2000). An economic method for the fluorescent labelling of PCR fragments. Nature Biotechnology 18:233-234.

Votava EJ, Baral JB, Bosland PW (2005). Genetic diversity of Chile (Capsicum annuum var. annuum L.) landraces from northern New Mexico, Colorado, and Mexico. Economic Botany 59:8-17.

Yi G, Lee JM, Lee S, Choi D, Kim B (2006). Exploitation of pepper ESTSSRs and SSR-based linkage map. Theoretical and Applied Genetics 114:113-130. 